Volume 7 Nomber 1, Februari 2021
P-ISSN: $2356-4164$, E-ISSN: $2407-4276$
Open Access at : https://ejournal.undiksha.ac.id/index.php/jkh
Program Studi Ilmu Hukum Fakultas
Hukum dan Ilmu Sosial
Universitas Pendidikan Ganesha Singaraja

\title{
Implementing Sustainable Finance Principles: Legal Implications of Ease of Doing Business Towards Banking Credit Approval
}

\author{
Bagus Saragih', Lastuti Abubakar'2, Tri Handayani ${ }^{3}$ \\ ${ }^{1}$ Fakultas Hukum, Universitas Padjajaran \\ E-mail : bagus17001@mail.unpad.ac.id \\ ${ }^{2}$ Fakultas Hukum, Universitas Padjajaran \\ E-mail : lastuti.abubakar@unpad.ac.id \\ ${ }^{3}$ Fakultas Hukum, Universitas Padjajaran \\ E-mail :tri.handayani@unpad.ac.id
}

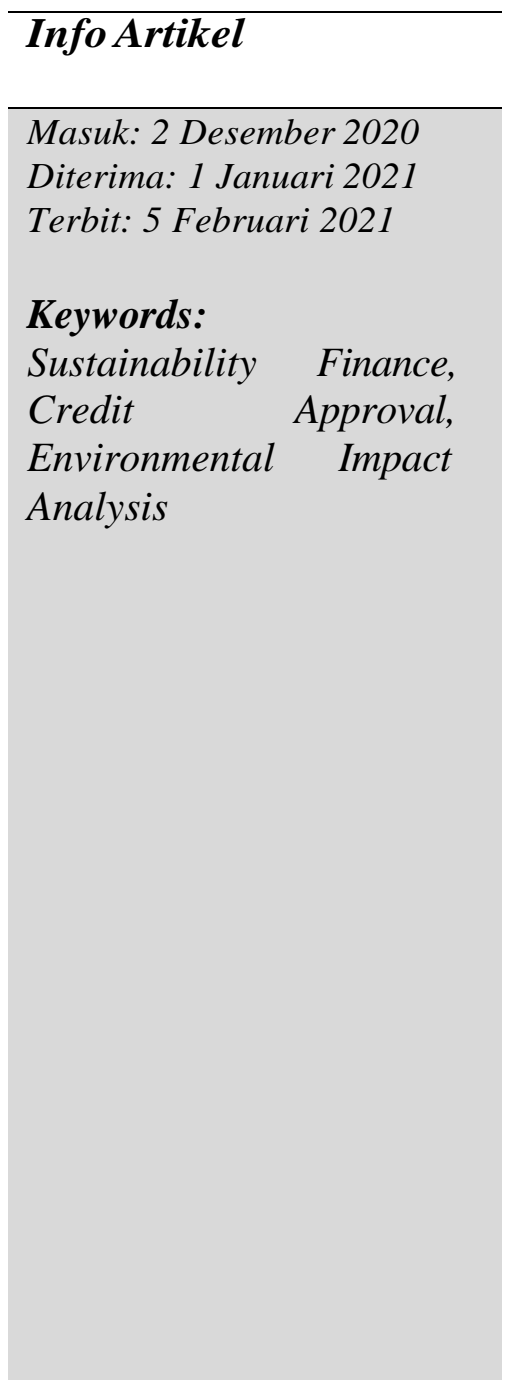

\section{Abstract}

The application of business licensing as a part of the ease of doing business has shifted the obligations present for business actors. One of the forms of said change is the absence of an obligation to conduct EIAs as a basic requirement to acquire a business license. This could boost investment in Indonesia. On the other hand, it also can prompt legal risks that are the revocation of business licenses towards actors that had failed to fulfill business license through OSS RBA. This provision impacts the application of the sustainable finance principle. Without the requirement of EIAs as the prerequisite of business licenses, banks gain the challenge of adjusting their approach towards the gaining of profits from long-term investments depends on a sustainable future on administering of credits by banks. The article aims to analyze the legal implications of changing regulation upon EIAs requirement on business licensing through Online Single Submission towards the application of the sustainable finance principle and the juridical consequences of the use of licenses based on commitments in the approval of bank credit. This research uses a normative juridical approach specifying in the descriptive analysis of primary and secondary law sources. The changed regulation upon EIAs requirement on business licensing through Online Single Submission has legal consequences for the bank to adjusting lending based on the debtor's business activity stages and requiring EIA as the basis to provide credit on the applications of sustainable finance principle. Sustainable principle pushed out the alteration of banks' approach in the 
initiation of sustainable economic development with the gaining of profits from long-term investments dependant on future sustainable policy frameworks. The bank must take that approach is through policy frameworks that support sustainable economic development by crystallizing EIAs as a tool for credit decision.

@ Copyright 2021.

\section{A. INTRODUCTION}

National development could be defined as a collective effort in self-repair towards a better tomorrow(Yorisca, 2020). Therefore, concepts regarding national development is a conscious effort from society to achieve its welfare. In the realization of national development goals, the progression of general welfare also considers the function of development as a realization of a prosperous and just society. The government has sent forth deregulation packages for increasing the national economy's efficiency that is felt by capital holders that the investment climate in Indonesia is less than conducive for the continuity of their business(Panjaitan \& Sianipar, 2008). Based on an index issued by the World Bank dubbed as the EODB, licensing related to establishing a business and access to credit are two out of eleven indicators that signify whether a country provides for easiness in doing business or not(Asmara et al., 2019). To cater this deficiency, the Indonesian Government is adamant in conducting policy reforms to facilitate a less stringent requirement in setting up a company (Arliman, 2019). This serves as the basis for the Government to attract and boost investors' confidence in establishing business in Indonesia.

In order to manifest said reform, Government Regulation Number 24 Year 2018 concerning Electronically Integrated Business Licensing Services ("GR OSS") uplifted Environmental Impact Assessments ("EIAs") as a requirement for business licensing, as the EIA is now merely a form of fulfillment towards commitments made by actors to create said EIA. The crux of the Government's stance in catalyzing the ease of doing business is ultimately regulated by Law Number 11 of 2020 concerning Cipta Kerja ("Cipta Kerja Law"), in which business licenses are issued only from a risk-based approach.

However, GR OSS and Cipta Kerja Law are in contradiction with the concept of sustainable development, which aims to achieve collective welfare(Yorisca, 2020). This concept originates from the unlimited number of human needs that cannot be satisfied by limited natural resources(Rosana, 2018). This concept generally integrates three aspects, namely economic, social, and environmental. The latest derivative of sustainable development, which this paper aims to elaborate is sustainable finance. Essentially, the fundamental principles of sustainable finance dictates that financial investments must serve as a trajectory towards long-term sustainable development projects and initiatives, as well as the promulgation of policies that support sustainable economic development based on economic, social, environmental, and governance systems.

On that note, banks, whom functionally are intermediaries play a crucial role in supporting sustainable development, as enshrined in Presidential Regulation Number 59 Year 2017 concerning the Implementation of Achieving the Sustainable Development Goals. Furthermore, Financial Services Authority Regulation Number 51 /POJK.03/2017 concerning the Implementation of Sustainable Finance for Financial 
Services Institutions, Issuers, and Public Companies ("FSAR SusFin") necessitate banks to apply sustainable finance principles in channeling funds owned by the public to business actors by virtue of extending credit to customers under the principles of protection for environmental management. The same thing has also been mandated by the Indonesian Banking Law, which obligate banks to inspect EIAs before granting credit approval for large-scale companies and/or companies with high risk in environmental pollution.

We could clearly see the two polarizing legal stances from our previous elaboration. In the context of ease of business, licensing through GR OSS and Cipta Kerja Law does not require an EIA for a company to conduct its business, This results in a legal overlap on whether banks are required to make an EIA as a requirement for credit approval for large-scale companies or companies with environmental pollution risk.

Based on the aforementioned explanation, further analysis on the necessity adjustment carried out by banks to provide credit approval for large-scale companies or companies that have a risk of environmental pollution must be done. Two problems that will mainly discuss in this article are: First, how juridical implication of regulatory developments on EIA requirements under GR OSS and Cipta Kerja Law towards credit banking policy for implement the sustainable finance principle?. Second, how banking legal consequences on using business license through OSS as a basis for granting credit in the terms of the prudential banking principle?

\section{RESEARCH METHODS}

This study uses a normative juridical approach with analytical descriptive specifications. This is done with the aim of being able to have findings, replacements or amendments from various theories in the legal discipline through a scientific process (Zaini, 2011). This approach is sourced from studies of selected literature derived from secondary data, including primary legal materials in the form of statutory regulations, secondary legal materials such as the results of previous research in the form of journals or articles and sustainable financial reports, as well as tertiary legal materials (Abubakar \& Handayani, 2019).

\section{B. DISCUSSION}

\section{Juridical Implication of Ease of Business Licensing in the Administering of Credit by Banks in Sustainable Financing}

Ease of doing business has an indirect legal impact on the implementation of the principles of sustainable finance. Business actors get exclusive rights granted by a set of laws and regulations relating to the simplification of business licensing implemented in GR OSS and reinforced by the Cipta Kerja Law in risk-based business licensing.

In accordance to the GR OSS, there is a form of simplification and convenience in processing permits for legal frameworks regarding permits based on commitments that have changed the application and issuance of Environmental Permits in the Government Regulation on Environmental Permits. In the licensing procedure set forth by the GR OSS, commitments can serve as a basis for issuing business licenses for business actors who need infrastructure in the execution of their business and/or activities. Business actors should give further commitments in the form of EIAs.

In the other hand, the Draft Government Regulation on Business Licensing Services in the Regions has been issued on 11 January 2021 to applicate Cipta Kerja Law. On that Draft GR, there are provision can change the substantive provision of licensing procedure on GR OSS in order to more simplification and convenience in processing business license with Risk-Based Approach. The Draft GR has been explained the Risk-Based Approach ("OSS RBA") system that business licensing is divided into two, that is industrial business and service business. As well as the different stages which are detailed as follows: 
1. Industrial Business
a. Preparation Stages
b. Operational Stages
c. Commercial Stages

2. Service Business

a. Preparation Stages

b. Operational and Commercial Stages

In addition, to implementing the Risk Based Approach on Cipta Kerja Law, Business Licensing for just high-risk business activities requires business registration number ("NIB") and Permits. The NIB applies at the preparation stage, and an NIB and Permit including EIA as bases of Environmental Approval from Government is required at the operational and commercial stages.

The following is the concession given to business actors in carrying out activities without using EIA as a requirement for a business license on GR OSS and Draft GR on Business Licensing Services in the Regions:

\section{GR OSS}

By obtaining a commitment-based business license, the business actors can carry out various activities, such as:

1. Land Procurement

2. Changes in land area

3. Procurement of equipment or facilities

4. Procurement of human resources

5. Completion of certifications or eligibility

6. Implementation of production trials and / or

7. The execution of Production
Draft GR (OSS RBA)

By obtaining a NIB, the business actor can carry out various activities to do the preparatory stage, such as:

1. Complete company legality or the Business Licensing process at OSS system

2. Land Procurement

3. The construction and operation of buildings

4. Procurement of machinery/ equipment, and/or

5. Procurement of human resources

Based aforementioned data, there is a setback in the EIA requirements which give business actors flexibility to carry out business activities without basing it with EIA. This results in an undermining of the essence of the principle of prevention in environmental protection(Mubarak, 2018). This still structurally alters the licensing procedure that has been regulated in Indonesian Environmental Law, which allows business actors to carry out all business activities such as procurement of facilities, land acquisition, and production trials up to the production stage as stated above after sustaining all procedures related to business licenses which includes EIAs.

Indonesian Environmental Law regulates sequentially the granting of business permits in stages starting from an EIA, an environmental feasibility ruling by the Minister of the Environment, an Environmental Permit, and a Business License(Mubarak, 2018). EIAs as a basis for environmental feasibility assessments have their role in forming sustainable development law as a prerequisite for the issuance of environmental permits in the licensing procedure based on Indonesian Environmental Law to ensure environmental feasibility.

Although in banking perspective, this certainly makes it easy for banks to be able to finance projects that will be carried out by business actors conducting their business activities. Particularly in starting debtor business, there was possibilities banks can channel the collected public funds to be channeled to large-scale business actors even though they have a high risk of environmental pollution before they could convey the EIA's result.

Furthermore, the issuance of business licenses through OSS-RBA that possibly the business actor to carry out several activities without EIA has legal consequences for the uncertainty of environmental protection manifested as EIAs. This uncertainty causes the bank to adjust its lending to the debtor's business activity stage. There are differences in bank treatment according to the stages of the debtor's business activities which are divided into two, namely: First, granting credit during the preparation stage, banks cannot use a business license as a tool to grant credit approval to 
large-scale business actors who have a high risk of environmental pollution with an approach riskbased at the preparation stage. Even after a business actor obtains an NIB as a business license, the bank needs to withhold all transactions before the business actor can submit the EIA results of the basic license to carry out the operational and/or commercial stages. Second, providing credit at the operational and/or commercial stages, banks in providing credit facilities to large-scale business actors who have a high risk of environmental pollution at the operational and/or commercial stages can be based on a business license through OSS. However, banks are obliged to continue to ensure that the business license of the business actor has environmental approval completed by EIA.

This is based on view of bank as a supporting factor for development, Banks are demanded that public funds collected by banks must be channeled for productive purposes in order to support the implementation of national development, assist in increasing the rate and equitable distribution of economic growth, and national stability towards improving the welfare of the wider community through loans providing to debtors. Indonesian Banking Law gives an obligation to creditors to be responsible for the decision to provide credit in a wider scope, including on social responsibility. Therefore, the role as agents of development emphasizes that banks need to pay attention to moral and social considerations to a certain extent, not solely based on economic considerations.

Furthermore, the obligation large-scale business actors or environmental high-risk companies to conduct EIAs in providing credit as stipulated in Indonesian Banking Law as a form of protection for environmental management is embodied in the policy of providing bank credit by providing obligations to banks in providing mandatory credit based on an in-depth analysis of the ability and capability of a Debtor Customer to pay off their debt or return the financing as promised. With an explanation that, in providing credit, banks must pay attention to the results of the EIAs for largescale and/or environmental high-risk companies so that the project being financed maintains environmental sustainability.

In its development, regulations in the banking sector have mandated an integrated understanding of economic, social, and environmental aspects based on FSAR Susfin. This provision is intended so that good business climate and a sustainable environment become a goal in banking activities. Project financing by environmentally sound banks has been proven to increase competitiveness and provide a distinct advantage in business strategy(Maramis, 2016). Article 2 paragraph (2) of FSAR Susfin explains eight principles that serve as a reference in implementing sustainable finance principles.

The one of the principles of sustainable finance that obliges banks to invest responsibly. Based on FSAR Susfin, there are three essential aspects in implementing the principle of responsible investment. First, banks take a financial investment approach to projects with sustainable development initiatives. Second, bank policies support sustainable economic development. Third, bank confidence in creating long-term investment profits lies in the economic, social, environmental, and governance systems. It refers to the principle of responsible banking issued by The United Nation Environment-Finance Initiative (UNEP-FI), namely the 'alignment principle'(Abubakar \& Handayani, 2019). The alignment of strategies to create consistency between creating bank profit value and articulating globally agreed goals and challenges, for example, the Paris Climate Agreement. Sustainable Development Goals, and other frameworks for building a more sustainable future(UNEP-FI, 2019). In addition, with a parallel strategy between profit creations with the common goal of realizing sustainable development, banks, through their business activities, can support a sustainable future by achieving long-term benefits(UNEP-FI, 2019).

Based on the above explanation, it can be concluded that the bank's obligation to encourage a financial investment approach reach the point for the bank to support the projects with sustainable development initiatives through the result of EIA on proceeding the large-scale business actors or environmental high-risk companies. Not NIB as Business license on preparation stage, nor Business License on operational and/or commercial stages only without the result of EIA. Bank should make and carry out environmental aspect requirements on their credit policies that support sustainable economic development. Inasmuch as in the execution on the several bank sustainability report in 2019, Bank has its interpretation on meaning sustainable finance principle, primarily responsible banking investment.

There is a definition of sustainable financing by banks that differ from the original intent of sustainable financing. For example, PT Bank Central Asia, Tbk ("BCA") separates a certain category of credit/financing with Environmental, Social, and Governance perspectives as stated in their 2019 sustainability report(BCA, 2019). BCA emphasizes that as a social-environmental risk management policy and governance, it is the application of the exclusionary principle which 
includes, among other things: First, the obligation for debtors to fulfill EIA, UKL-UPL requirements and if the debtor has an environmental conservation certification, then this credit will be categorized as financing with environmental, social and governance aspects. Second, BCA focuses on monitoring credit extended to its customers through the results of environmental management performance assessments issued by the Ministry of the Environment (PROPER). However, BCA provides the possibility for debtors who have not met environmental requirements. BCA can monitor developments periodically.

On the other side, PT Bank Negara Indonesia, Tbk ("BNI") (Bank Negara Indonesia, 2019) emphasizing to use of the result of the Company Performance Rating Program in Environmental Management or is called ("PROPER") issued by the Ministry of Environment and Forestry as BNI Commitment to ESG aspect on sustainable finance principle. BNI highly does not provide credit to business owners with a Red and Black PROPER rating without anticipatory action. Other than that, BNI also conducts compliance tests on loan proposals prior to granting credit decisions by the Credit Committee. The results of the compliance are one of the considerations for the Credit Committee in making decisions. However, BNI provides flexibility to follow up for compliance test results that do not meet the requirements, can be fulfilled within a certain period before or after the loan disbursement. Based on aforementioned data of practically approval credit banking procedure, there is shifting on emphasizing the using result of EIA and PROPER to monitoring business actors to preserve the environment based on providing the credit. The different meaning of sustainable finance on several banks in the principle of responsible investment must be interpreted to the changing in banks' approach for all investments made by banks aimed at projects with sustainable development initiatives through banking policies supporting sustainable economic development. This can be done starting with a strong belief held by the bank that the creation of long-term investment returns lies in the economic, social, and environmental systems.

Indonesian Banking Law certainly gives banks an obligation to implement the principle of prudence. This is done by better understanding the environmental protection of the management executed by prospective debtors who have a high risk of environmental pollution for the loans they are given. Not only on periodic supervision by banks but the implementation of the prudential banking principle must also be carried out based on the results of an EIA as one of the bases for banking credit policy(Maramis, 2016).

The difference in the meaning of sustainable finance principles in banking certainly has an interconnection with the meaning of the bank's prudential principles in question. Prudential banking principles is the main principle that underlies all banking activities(Abubakar, 2018). In the case of banks being lenders, the prudential banking principle is the belief in the ability and capability of customers as a crucial preventive factor in controlling credit risk by banks in providing a credit against credit misuse by debtors, which results in the default of debtors(Mulyati \& Dwiputri, 2018).

In the context of the implementation of the prudential banking principle, there are three perspectives in the implementation of the prudential banking principle(Damanik, 2020). First, banks must apply the principle of prudence as a financial institution that collects public funds and business strategies and all processes of banking business activities. This is directly related to implementing the precautionary principle that must be implemented immediately, starting from the time the bank in question is considered legally valid. If a bank is established in the form of a limited liability company, all the requirements must be met are the regulations relating to a said category of company. In addition, all processes and procedures used by banks in the execution of all banking activities must comply with all applicable regulations to apply the prudential banking principle. Secondly(Abubakar \& Handayani, 2017), the meaning of the prudential banking principle is interpreted narrowly through credit funneled by banks to directly enable customers and prevent failure to pay by customers to achieve the required health level. Thirdly, the meaning of the prudential banking principle is only carried out to avoid bank losses to protect depositing customers' interests. This shows that the prudential banking principle cannot be interpreted only as of the provision in administering bank credit to prevent default by customers to maintain the soundness of the banking system. However, banks as financial institutions are also obliged to integrate economic, social, and environmental aspects. In each of these banking business activities based on FSAR Susfin. This can keep banks prudent on every requirement they must fulfill by implementing specific sustainable finance principles in providing credit using an EIA as a credit decision tool.

The need for defining the prudential principle in banking is based on several reasons which are the reasons for the importance of banking to observe the prudential principle as follows(Abubakar, 2018): 
1. Banks as agents of development, in accordance with Article 3 of Indonesian Banking Law, has the function to gather funds and distribute those funds towards third parties as well as being a mover of the economy by assisting in the development of the real sector through funds funneled to the public using a variety of economic activities such as investment, the distribution or consumption of goods and/or services. This is crucial towards the macroeconomy having the effect towards financial system stability when those intermediary functions are not being executed as it should be, which definite creating a setback from sustainable development goals.

2. In the context of the risk management obligations in administering credits, banks have risks in the credit it funnels, having the effect of loss in the event of failure to pay or faulty credit. Banks as financial service institutions also need to add environmental, social, and governance risks as banking risk management in the effort to implement the principle of risk and environmental management(Abubakar \& Handayani, 2019). This becomes an essential factor for banks to consider the social, economic, and environmental aspects in the execution of risk management relating to credit administration.

Therefore, the shifting of financial investment approaches by banks towards projects with the intention of sustainable development through policies supporting sustainable economic development has its connection to the obligation of conducting an EIA owed by the debtor to conform to Indonesia's commitment to the principle of sustainable financing. This is executed as a compliance measure towards a bank's policy in administering credit before debtor initiating their operational activities. Even though with business licencing through GR OSS and Cipta Kerja Law, it is possible debtors were already possessing a business license to bear the right to execute business activities in the preparation stage without having to conduct an EIA.

To adapting the potential of legal implication to the shifting license procedures in the business license through OSS-RBA, prompting the legal need for amending procedure in bank policy regarding the administering credit. Under the principle of responsible investment, a credit policy that supports sustainable economic development is applied using EIAs as one of decision tools to credit approval and cannot base a credit on business licenses through OSS-RBA. This is based on the use of business licenses as a basis for credit approval, increasing the legal risk over permit revocation based on a failure fulfilling EIA to continue the operational/commercial stages. The usage of business license through OSS-RBA can increase the risk to credit and the reputation of the bank, which should already be anticipated in banking risk management to uphold the principle of responsible investment in sustainable financing. This has become an adaptation that banks should make in making policies regarding credit approval through bank credit guidelines by upholding the prudential banking principle in the broadest sense of the term that supports sustainable economic development under sustainable financing. That has become the basis for banks' obligation to further analyze results from EIAs before giving credit approval and not the Business Licensing through OSS-RBA as a tool for upholding the principle of responsible investment being one of the principles of sustainable financing.

\section{The Legal Implication of the Usage Business Licensing through OSS-RBA towards Bank Credit Approval}

Under the business licensing procedure set forth within the OSS-RBA, business actor can start their preparatory activities without basing on EIA. Therefore, bank in channeling loans to customers, especially large-scale debtors and having a high risk of environmental pollution, it possibly to carried out during the preparation stage for the debtor's business activities. However there lies a possibility where debtor fail to fulfill the EIA as a basic requirement before the debtor carries out operational and/or commercial activities. This failure gave the OSS Agency the power to revoke issued business licenses when actors do not fulfill EIA. Aside from that, actors' fulfillment is also judged by Decrees relating to the environment set forth by the Minister of the Environment. In the case where actors are said to be unfit environmentally, business licenses are then considered to be null-and-void. Legally, this unable banks in using the broadest sense of prudence in implementing the principle of sustainable financing, specifically in credit approvals that do not require EIAs.

There are a few aspects that is impacted by the use business licensing through OSS-RBA on credit approval, inter alia: 


\section{The Aspect of Banking Risk}

One of the effects of the usage business licensing through OSS-RBA i.e. increased risks for banks. According to Financial Service Authority Regulation Number 18/POJK.03/2016 regarding the Implementation of Risk Management for General Banks ("Risk Management FSAR"), risk is described as the potential of loss that is caused by a certain event in relation to the operations of general banks. Risk management holds an important role in anticipating the potential for loss over the commencement of banking business activities through the process of planning, organizing, leadership and control as to fulfil set goals, whereas bad management could result in a risk of loss to banks if the risk is not recognized or managed duly (Siregar, 2014).

Article 1 Paragraph 3 of the Risk Management FSAR defines the role of risk management as methodologies and procedures to identify, measure, monitor, and control risks arising all banking activities. This role is conducted through a number of steps including the management of risk (Siregar, 2014). Furthermore, the Risk Management FSAR also lists number of risks that banks face in every business activity, inter alia: credit risk, market risk, liquidity risk, operational risk, legal risk, reputational risk, strategical risk, and compliance risk. Specifically, in administering credit without the need for EIAs as a requirement for approval, there's number of risks, among other things:

1. Credit Risk

Based on Article 1 point 4 of the Risk Management FSAR, credit risk is a risk due to the failure of other parties to fulfil obligations to the bank, including credit risk that can arise due to the failure of the debtor to pay off his debt. Credit risk can be divided into three categories, including (Abubakar, 2018): First, Credit Concentration Risk or risk arising from concentrated credit that is concentrated on banking credit facilities to one party or group of parties, industry, and / or certain geographic areas which provides a large potential for losses and threatens the survival of the bank. Second, Counterparty Credit Risk, namely the credit risk to the counterparty over a derivative contract or the risk arising from the failure of the counterparty to fulfil its obligations from transactions that have certain characteristics, these characteristics differentiate from other credit risks towards the value underlying the contract that cannot be ascertained in the future, in the form of magnitudes or signals (Gregory, 2010). Third, Settlement Risk, namely the risk of failure to deliver cash and / or financial instruments on the settlement date based on sales and/or purchase transactions of financial instruments.

The same could be said of credit risk arising from customer obligations that have been facilitated by bank credit that will significantly increase when the customer does not fulfill the form of EIA on preparations stages. In addition, the credit risk also increases if a customer fails to obtain environmental feasibility standards in the EIA results when assessed by the EIA evaluation commission, which states that the Debtor does not meet the requirements for environmental protection contained in the EIA. Therefore, the customer's business license will become null-and-void, this will result in the credit facility becoming a non-performing loan. This occurs belief of banks is not realized that the customer is able to repay the loan and interest of the credit when the customer does not have a business license to run his business (Herijanto, 2014).

2. Reputation Risk

Banks as agents of trust that have an intermediary function must ensure that the public feels safe to keep their funds at any time, to which they can get liquidate said money and the interest promised in full (Herijanto, 2014). Likewise, the reputation risk defined by Article 1 point 10 of the Risk Management FSAR is the risk due to decreased levels of stakeholder trust which comes from negative perceptions of the bank. As a second-degree risk, reputation risk cannot be ruled out by credit risk as a trigger for high reputation risk (Afriyeni \& Susanto, 2019). Adiwarman explain that positive appraisal from stakeholders will result in a low reputation risk, if service given to stakeholders is rated negatively then the opposite is true. This of course resulted in negative publicity which led to an increase in the level of reputation risk in banks(Afriyeni \& Susanto, 2019). Therefore, the violation of the application of the precautionary principle in lending without analyzing the results of EIAs in the context of implementing the principle of responsible investment in sustainable finance, of course, has an indirect impact on the reputation risk received by banks in 
addition to credit risk.

\section{The Aspect of Credit Loan Agreement}

Credit, under Indonesian Banking Law, is stated as supplying money or its equivalent claims based on an agreement between the bank and the customer, which gives the customer the obligation to pay off his debt after a while by giving interest. This provision describes a legal relationship between banks as creditors having an obligation to provide money or their equivalent to customers. On the other hand, the customer should pay off his debt plus the interest determined according to the time determined based on the credit agreement.

The credit agreement has a special characteristic that is almost the same as the loan-and-use agreement stipulated in Article 1754 of the Indonesian Civil Code. However, there are different elements at the entry into force of the credit agreement. An explanation for this is that credit, as an anonymous agreement, is divided into two parts that are side-by-side and related. First, the preliminary agreement to enter into a loan-and-use agreement is an agreement subject to the general section of book III of the Indonesian Civil Code. Second, a borrow-and-use agreement that is subject to the provisions of Articles 1754 to 1759 and the general provisions of Book III of the Indonesian Civil Code. The borrow-and-use agreement will affect the delivery of money or its equivalent from the bank to the customer. Meanwhile, a borrow-and-use agreement in credit agreements will not be possible without being preceded by a predecessor agreement(Sucipto, 2011).

In the process of administering credit, the Article 8 Banking Law govern the obligation for banks have to execute an "in-depth analysis" which emphasizes two points of substance, which are (Herijanto, 2014): First, the decision-making process. This process requires an in-depth analysis to gain confidence in the debtor's ability and capability to pay off his debts. Analysis conducted by banks to obtain confidence in debtors is clearly written in Indonesian Banking Law, the principle commonly known as the $5 \mathrm{C}$ 's analysis of credit. This belief is based on a careful assessment of character; capacity; capital; collateral; and (economic) conditions (Abubakar \& Handayani, 2017). This is done through several requirements that must be met by prospective debtors to anticipate and minimize risks arising from the administering of credit (Herijanto, 2014).

Second, the materials for decision making. The meaning of material for decisions are information, data, and / or facts required by credit analysts. Information, data or facts are largely determined by the desired outcome, namely confidence in the debtor's good faith, ability, and capability to pay off debts. Regardless of the relativity of the sufficiency of required information, the obtainment of this information is necessary to keep banks prudent in providing credit decisions to debtors (Herijanto, 2014). One of the information that banks must have before administering credit to prospective debtors who have a high risk of pollution are EIAs. As a legal formality based on Indonesian Banking Law, EIAs provide adequate information which requires sufficient expertise and knowledge in the environmental sector. Therefore, problems could be identified with environmental expertise in several sustainability reports of banks in Indonesia in 2019.

Therefore, if the business license through OSS-RBA provides the possibility of using a business license by banks in providing bank credit without requiring EIAs, some restrictions need to be considered by banks. First, the stages of the debtor's business activities, the division of stages is clearly regulated in Articles 25 and 26 of the GR Draft on Business Licensing Services in the Regions. The debtor can only carry out the preparatory stage as long as they has not obtain the EIA results as the basis for the validity of the business license at the operational and commercial stages. Second, EIA result, as basis on environmental feasibility decision that became the limit of business licenses granted that could still be valid when actors receive an environmental feasibility decision from the government under their authority to continue the operational and/or commercial stages.

However, if it refers to the validity of the credit agreement as an anonymous agreement addressed to the provisions of Article 1319 of the Indonesian Civil Code, then the provisions of book III of the Indonesian Civil Code concerning agreements born out of the agreement is applicable. The validity of the credit agreement refers to provisions set forth in Article 1320 regarding the validity requirements of agreements, which are(Sucipto, 2011):
a. Conformity of intent
b. legal capacity to enter into agreements
c. A specific object of agreement
d. Lawful causes. 
There exist potential legal consequences for the use business licensing through OSS-RBA by banks without EIA basis in credit agreements beyond the limit set by GR OSS and Cipta Kerja Law. The legal effect on the credit agreement is divided into two, which are:

a. Cancellable Credit Agreements

Assessed from the provisions of Article 1320 of the Civil Code regarding the validity of agreements, with the legal consequences of the cancellation of the business licenses issued by the OSS agency, the credit agreement can be canceled by the Bank. This is a legal consequence of not fulfilling personal legal requirements, namely the customer's ability to carry out an agreement to carry out his performance in the Credit Loan Agreement. Under responsible banking, The credit loan agreement cannot be only interpreted as a legal relationship between the bank and the customer's provision of money. The Credit loan agreement must be interpreted as tools to support a sustainable future by achieving longterm benefits.

b. Credit Agreements being rendered Null-and-void

Based on Article 1335 of the Indonesian Civil Code, an agreement made based on a prohibited cause has no legal force. The meaning of 'forbidden cause' is explained as a cause prohibited by law. If a debtor, especially a debtor who has a high risk of environmental pollution, fails to fulfill EIA for basic requirement of business license on operational and/or commercial stages, it can adequately explain the credit agreement between the bank and the customer is against the original intent of Indonesian Banking Law. Indonesian Banking Law obliges banks to conduct an in-depth analysis of the EIA made by high-risk debtors so that the project being financed maintains environmental sustainability. In addition, banks have failed to apply the principle of responsible investment, which obliges banks to approach sustainable economic development based on FSAR Susfin. Therefore, the failure to fulfil EIA for basic requirement of debtor's business license obtaining legal effect of the credit agreement that has been made by the bank and the debtor not be legally enforceable, such as the state before the business license that is null-and-void.

In anticipating the legal consequences of the cancellation business licenses in credit agreement and in taking a supportive approach to sustainable economic development, banks are required to carry out double protection that is to be stipulated in the credit agreement. Banks must include a clause in the credit agreement, including:

1. Condition Precedent in the making of EIAs

Assessing from the nature of credit in itself and projects financed by banks, projects with a high risk of environmental pollution obliges banks to include EIA requirements before the credit agreement takes effect and is binding to the bank and the debtor. With the ease of business licensing that allows the debtor to carry out several activities on the preparation stages before the EIA results, the Condition Precedent clause's inclusion on the EIA results and not a business license is a firm condition of the credit agreement.

2. Affirmative Covenant dan Negative Covenant in the making of commitments.

These banking obligations on principle of responsible investment can be realized based on clauses in credit agreements. With the ease of business licensing through OSS-RBA, banks must include an affirmative covenant clause regarding the obligation of business actors to commence EIAs within 30 days from the issuance of NIB as business license on the preparatory stage. Besides, the negative covenant clause provides an obligation for debtors not to violate laws and regulations regarding environmental management, and debtors are prohibited from fulfilling their business license through OSS.

3. Event of Default, specifically, the revocation of business licenses through OSS RBA

If in the implementation of the credit agreement the debtor does not obey the provisions in the affirmative covenant and negative covenant clauses, the bank is 
obliged to include the cancellation of the business license as caused by debtor's failure to provide EIA before operational and/or commercial stages as a condition of negligence. Inclusion of an event of default clause provides the right to cancel the credit agreement in response to the failure to fulfill the debtor's commitments. This is carried out as a form of repressive supervision applied by banks periodically.

\section{CONCLUSION}

The issuance of business licenses through OSS-RBA has legal consequences for the uncertainty to encourage bank for adjusting lending based on the debtor's business activity stages. This affects the execution of banking regulations intended to amend the banking approach through the understanding between economic, social, and environmental aspects based on FSAR Susfin. Although on the several sustainable reports in 2019 there are banks who has their own interpretation to carry long-term investment, Bank should comply with the original intent on FSAR SusFin as part of implementing the prudential banking principle. This is related to the obligation to conduct EIAs to debtors as the formal legal provision of credit.

The use of business licenses through OSS-RBA provides a potential increase in credit risk and reputation risk for banks that should have been anticipated beforehand in risk management. Potential risks arise if the debtor fails to fulfill to compile the EIA and fails to obtain an environmental feasibility decision.

\section{RECOMMENDATION}

In enforcing sustainable finance principles, banks must had credit policies that assess EIA as the basis for making credit decisions to prevent mismatches or deviations resulting from business license.

In anticipating the legal consequences for the cancellation of the business license in the credit agreement. Banking must be a clause in the credit agreement to realize bank supervision of credit provided to debtors with environmental pollution risk, namely: Condition Precedent, Affirmative Covenant, Negative Covenant, and Event of Default.

\section{REFERENCE}

\section{Books:}

Gregory, J. (2010). Counterparty Credit Risk: The New Challenge for Global Financial Markets. John Wiley \& Sons Ltd.

Herijanto, H. (2014). Prinsip Keputusan Bisnis Pemberian Kredit Perbankan Dalam Hubungan Perlindungan Hukum (E. Damian (ed.); 1st ed.). PT ALUMNI.

Panjaitan, H., \& Sianipar, A. M. (2008). Hukum Penanaman Modal Asing. CV INDHILL Co.

\section{Convention and Regulation}

Undang-Undang Dasar Negara Republik Indonesia Tahun 1945.

Undang-Undang Nomor 7 Tahun 1992 tentang Perbankan. 
Undang-Undang Nomor 10 Tahun 1998 tentang Perubahan atas Undang-Undang

Nomor 7 Tahun 1992 tentang Perbankan

Undang-Undang Nomor 32 Tahun 2009 tentang Perlindungan dan Pengelolaan

Lingkungan Hidup

Undang-Undang Nomor 11 Tahun 2020 tentang Cipta Kerja

Peraturan Pemerintah Nomor 27 Tahun 2012 tentang Izin Lingkungan

Peraturan Pemerintah Nomor 24 Tahun 2018 tentang Pelayanan Perizinan Berusaha Terpadu Melalui Sistem Elektronik

Peraturan Presiden Nomor 57 Tahun 2017 Tentang Pelaksanaan Pencapaian Tujuan Pembangunan Berkelanjutan.

Peraturan Otoritas Jasa Keuangan Nomor 51 /POJK.03/2017 Tentang Penerapan Keuangan Berkelanjutan Bagi Lembaga Jasa Keuangan, Emiten, dan Perusahaan Publik

Peraturan Otoritas Jasa Keuangan Nomor 18/POJK.03/2016 tentang Manajemen Risiko Bagi Bank Umum

\section{Journal dan Scientific Publication}

Abubakar, L. (2018). IMPLEMENTASI PRINSIP KEHATI-HATIAN MELALUI KEWAJIBAN PENYUSUNAN DAN PELAKSANAAN KEBIJAKAN PERKREDITAN ATAU PEMBIAYAAN BANK.

Rechtidee.

https://doi.org/10.21107/ri.v13i1.4032

Abubakar, L., \& Handayani, T. (2017). TELAAH YURIDIS TERHADAP IMPLEMENTASI PRINSIP KEHATI-HATIAN BANK DALAM AKTIVITAS PERBANKAN INDONESIA. De Lega Lata. https://doi.org/10.31219/osf.io/acxqu

Abubakar, L., \& Handayani, T. (2019). Implementation of the Principles for Responsible Banking in Indonesian Banking Practices to Realize Sustainable Development Goals. 358(Icglow), 103-106. https://doi.org/10.2991/icglow19.2019.26

Afriyeni, A., \& Susanto, R. (2019). Manajemen Risiko Pada Bank Syariah. 658-661. https://doi.org/10.31219/osf.io/yj9kb

Arliman, L. (2019). Role Investment in Development Policy of Tourism Economics in West Sumatera Province. 20(2), 273-294.

Asmara, T. T. P., Ikhwansyah, I., \& ... (2019). Ease of Doing Business: Gagasan Pembaruan Hukum Penyelesaian Sengketa Investasi di Indonesia. University Of Bengkulu ....

Damanik, D. \& P. P. (2020). Prudential Banking Principles Dalam Pemberian Kredit $\begin{array}{llll}\text { Kepada Nasabah. } & \text { Notarius, } & \text { 12(2), }\end{array}$ https://doi.org/10.14710/nts.v12i2.29011

Gregory, J. (2010). Counterparty Credit Risk: The New Challenge for Global Financial Markets. John Wiley \& Sons Ltd.

Herijanto, H. (2014). Prinsip Keputusan Bisnis Pemberian Kredit Perbankan Dalam Hubungan Perlindungan Hukum (E. Damian (ed.); 1st ed.). PT ALUMNI.

Maramis, N. F. (2016). TANGGUNG JAWAB PERBANKAN DALAM PENEGAKAN GREEN BANKING MENGENAI KEBIJAKAN KREDIT. LEX ET SOCIETATIS.

Mubarak, A. R. (2018). Conflict of Interest antara Usaha Perlindungan Lingkungan Hidup dengan Kemudahan Berinvestasi dalam Peraturan Pemerintah. 5(2), 284- 
298.

Mulyati, E., \& Dwiputri, F. A. (2018). PRINSIP KEHATI-HATIAN DALAM MENGANALISIS JAMINAN KEBENDAAN SEBAGAI PENGAMAN PERJANJIAN

KREDIT PERBANKAN. Acta Diurnal Jurnal Ilmu Hukum Kenotariatan Dan KePPAT-An. https://doi.org/10.24198/acta.v1i2.112

Rosana, M. (2018). Kebijakan Pembangunan Berkelanjutan Yang Berwawasan Lingkungan di Indonesia. KELOLA Jurnal Ilmu Sosial, 1(1), 148-163.

Schoenmaker, D. (2018). A Framework for Sustainable Finance. SSRN Electronic Journal, January 2018. https://doi.org/10.2139/ssrn.3125351

Siregar, A. M. (2014). Peranan Manajemen Risiko Dalam Tugas dan Tanggung Jawab Direksi Bank Berdasarkan Peraturan Perundang-Undangan di Indonesia. Usu Law Journal, 2(1), 169-185.

Sucipto, S. (2011). Aspek-Aspek Hukum Perdata Dalam Penyaluran Kredit Perbankan Kepada Masyarakat. Asas Jurnal Hukum Ekonomi Syariah, 3(1), 13- 21.

http://download.portalgaruda.org/article.php?article=149549\&val=5885\&tit le=ASPEK-ASPEK HUKUM PERDATA DALAM PENYALURAN KREDIT PERBANKAN KEPADA MASYARAKAT

UNEP. (2019). Principles for Responsible Banking: Shaping our Future. November, 1.

Yorisca, Y. (2020). Pembangunan Hukum yang Berkelanjutan: Langkah Pejaminan Hukum Dalam Mencapai Pembangunan Nasional yang Berkelanjutan. Jurnal Legislasi Indonesia, 17(1), 98-111.

Zaini, Z. D. (2011). Implementasi pendekatan yuridis normatif dan pendekatan normatif sosiologis dalam penelitian ilmu hukum. Pranata Hukum, 6(2), 117. 